\title{
The Role of Bacillus-Based Biological Control Agents in Integrated Pest Management Systems: Plant Diseases
}

\author{
B. J. Jacobsen, N. K. Zidack, and B. J. Larson
}

Department of Plant Sciences and Plant Pathology, Montana State University, Bozeman 59717.

Accepted for publication 7 July 2004.

\begin{abstract}
Jacobsen, B. J., Zidack, N. K., and Larson, B. J. 2004. The role of Bacillus-based biological control agents in integrated pest management systems: Plant diseases. Phytopathology 94:1272-1275.

Bacillus-based biological control agents (BCAs) have great potential in integrated pest management (IPM) systems; however, relatively little work has been published on integration with other IPM management tools. Unfortunately, most research has focused on BCAs as alternatives to synthetic chemical fungicides or bactericides and not as part of an integrated management system. IPM has had many definitions and this review will use the national coalition for IPM definition: "A sustainable approach to managing pests by combining biological, cultural, physical and chemical tools in a way that minimizes economic, health and environ-

mental risks." This review will examine the integrated use of Bacillusbased BCAs with disease management tools, including resistant cultivars, fungicides or bactericides, or other BCAs. This integration is important because the consistency and degree of disease control by Bacillus-based BCAs is rarely equal to the control afforded by the best fungicides or bactericides. In theory, integration of several tools brings stability to disease management programs. Integration of BCAs with other disease management tools often provides broader crop adaptation and both more efficacious and consistent levels of disease control. This review will also discuss the use of Bacillus-based BCAs in fungicide resistance management. Work with Bacillus thuringiensis and insect pest management is the exception to the relative paucity of reports but will not be the focus of this review.
\end{abstract}

Integration with host resistance. Integration of Bacillus-based biological control agents (BCAs) with disease resistant hosts has proven to be useful in management of several disease problems, particularly where high levels of disease resistance is not available, or where high yielding, highly resistant cultivars are not available. Published examples include Fusarium wilt of chickpea (8), Pythium torulosum damping-off of tomato (27), and Cercospora leaf spot of sugarbeet $(11,20)$. In each of these studies, disease control involving a Bacillus-based BCA was better on the more resistant cultivar. Data in Table 1 show that the application of Bacillus mycoides isolate $\mathrm{Bm} \mathrm{J}$ was more effective in controlling Cercospora leaf spot on the more resistant cv. HM 7054 than on the susceptible cv. Beta 2185. The research by Hervas et al. (8) showed that suppression of Fusarium wilt caused by race 5 of Fusarium oxysporum f. sp. ciceris was greater and more consistent on partially resistant cv. PV 61 with Bacillus subtilis isolate GB03 seed treatment than on the more susceptible cv. ICCV 4. Of interest is the interaction between inoculum load, host resistance, and influence of Bacillus subtilis isolate GB03. The effect of GB03 was significantly different from the pathogen control at the highest inoculum load on the susceptible cultivar and at only the lowest inoculum load on the partially resistant cultivar as measured by incubation period, disease index, and standardized area under the disease progress curve (AUDPC). Smith et al. (28), in their study of tomato inbreds with varying susceptibility to Pythium torulosum damping-off and Bacillus cereus isolate UW 85, showed that low inoculum doses are best for demonstrating differences in inbred disease resistance but that

Corresponding author: B. J. Jacobsen; E-mail address: uplbj@montana.edu

Publication no. P-2004-0916-070

(c) 2004 The American Phytopathological Society high inoculum doses are needed to show disease control by UW 85. Smith et al. (28) proposed a dose response modeling approach to integrate information on pathogen inoculum load, BCA dose, and host resistance. In their study, they showed that inbred tomato lines differed independently regarding pathogen resistance and their ability to support the BCA, UW 85 . They suggest that when breeding to improve disease resistance, both pathogen resistance and the ability to support BCAs should be considered.

In a 3-year study, Larson (20) showed that a BCA, Bacillus mycoides isolate $\mathrm{Bm} \mathrm{J}$, provided control of Cercospora leaf spot equal to synthetic fungicides as measured by AUDPC on a sugarbeet hybrid that had a moderate level of resistance, but isolate $\mathrm{Bm} \mathrm{J}$ provided only $41 \%$ of the control afforded by four fungicide sprays on the susceptible cultivar (Table 1). In a multiyear study with Bm J, this BCA provided 38 to $91 \%$ of the control of labeled fungicides on susceptible cultivars (1). The effect of Bm $\mathbf{J}$ application was to flatten the disease progress curve such that the economic threshold was exceeded too late in crop maturity to significantly affect yield. The moderately resistant cultivar, HM 7054, had a flatter disease progress curve than susceptible cv. Beta 2185 such that the economic threshold was exceeded later in crop maturity. This is characteristic of the rate limiting resistance found in these cultivars (27). By utilizing a moderately resistant cultivar and $\mathrm{Bm} \mathrm{J}$, the level of disease control was not statistically different from that of four sprays of fungicide on the susceptible cultivar. In this same study, Larson (20) compared AUDPC and yields of other moderately resistant and susceptible cultivars produced under a standard fungicide spray regime with a spray program utilizing $\mathrm{Bm} \mathrm{J}$. The data were similar to that described previously.

Osburn et al. (24) reported a similar set of experiments with Bacillus cereus isolate UW 85 seed treatments and soybean cultivars resistant, tolerant, or susceptible to Phytophthora root rot. In 
this research, UW 85 increased yields only on the susceptible cultivar where Phytophthora root rot was a factor. At another site where Phytophthora root rot was not a factor, both metalaxyl (in furrow and seed treatment) and UW 85 increased stands significantly over untreated seeds regardless of Phytophthora root rot resistance. A similar nonadditive response was shown by McGovern (23) for Fusarium wilt of basil and by Everts and Armentrout (6) for powdery mildew of pumpkin.

Integration with fungicides or bactericides. Since the review paper by Jacobsen and Backman (10) dealing with biological and cultural controls as alternatives and supplements to chemicals in integrated pest management (IPM) systems (10) there have been additional reports of using Bacillus-based BCAs with fungicides to achieve more stable control. Perhaps the most common combination of BCAs with fungicides is with seed treatments. Today nearly all cotton planted is treated with Kodiak (Bacillus subtilis isolate GB03) and fungicides (4). Brannen and Kenney (4) indicated that combining Kodiak with fungicides provides control of pathogens that are not controlled by available fungicides, and the BCA provides control via colonization of the rhizosphere long after the fungicides have degraded. Brannen and Kenney (4) suggest that success of Kodiak in the cotton market is due to integration with fungicides. Although not addressed by these authors, the fungicide will provide control under environmental conditions unfavorable for the BCA, or before the BCA has sufficiently colonized the rhizosphere. In addition, this Bacillus isolate also increases growth and plant vigor (14). In results reported by Multistate Research Project S 302 on cotton for 2001 (2), the combination of Kodiak and the standard fungicide treatment carboxin-PCNB-metalaxyl provided better stands than the standard fungicide treatment in one of five locations and was not significantly different from the standard fungicide in the other four locations, whereas Kodiak alone provided stands lower than the fungicide standard in four of five locations and was not statistically different from the standard fungicide in the other location. In 2002, cottonseed treatment tests of Kodiak plus carboxinPCNB-metalaxyl provided stands not statistically different from the standard carboxin-PCNB-metalaxyl seed treatment alone (3). Batson et al. $(2,3)$ showed similar data. Other Bacillus spp. were examined in these same trials, but none performed better than Kodiak.

Cook et al. (5) reported on the use of Bacillus sp. isolate L32492 , used alone and in combination, commonly used seed treatments, including difenoconazole plus metalaxyl, difenoconazole plus mefoxam, tebuconazole plus thiram, and tebuconazole plus metalaxyl for control of the wheat root rot complex that includes Gaeumannomyces graminis var. tritici, Rhizoctonia solani AG8, $R$. oryzae, and several Pythium spp. Yield increases were significantly higher for the difenoconazole plus mefoxam plus L324-92 treatment than for either the fungicide or the BCA alone on winter wheat. This effect was not significant for the other fungicide treatments on winter wheat, and there were no significant differences on spring wheat. There were no significant differences for control of take-all, but at one of four locations there were treatment differences for Rhizoctonia root rot on winter wheat. However, the BCA alone was as effective as the fungicides alone and the combination was not statistically different from these treatments, except at one location where the combination of tebuconazole plus thiram plus L324-92 provided a lower disease index than the fungicide alone, but disease control was not statistically different from the BCA alone. At another location, similar effects were seen with difenoconazole plus mefoxam.

The potential to use lower rates of fungicides when combined with a Bacillus-based biological control has not been well explored. Our lab group has studied the use of Bacillus pumilis isolate 341-16-5 as a seed treatment for the control of sugarbeet damping-off and root rot caused by Aphanomyces cochlioides, Pythium ultimum, and $R$. solani in combination with varying rates of hymexazol. In 14 location-years of testing, this isolate has increased both stand at harvest and yield when combined with 20 , 30 , or $45 \mathrm{~g}$ of hymexazol per 100,000 seed compared with that of hymexazol treatments alone. In addition, the 20 -g rate was as effective as the 45-g rate when combined with the BCA. Bacillus pumilis isolate 341-16-5 was not as effective as hymexazol when used alone, and the $20 \mathrm{-g}$ rate was not as effective as the $45-\mathrm{g}$ rate when used alone.

Reports on the use of Bacillus-based BCAs with fungicides for control of foliar diseases are relatively scarce. In a study of control of avocado black spot caused by Pseudocercospora purpurea, Korsten et al. (19) showed that, in eight location-years of research, Bacillus subtilis isolate B246 applied with copper oxychloride or with benomyl and copper oxychloride provided more consistent control than either the BCA or the fungicides alone. The integrated program allowed for fewer fungicide sprays, and Korsten et al. (19) suggested that the integration of fungicides acted as a safeguard in those years unfavorable to BCA activity. In other work on sugarbeet, Kiewnick et al. (16) reported that the combination of Bacillus sp. isolate MSU 127 and $76 \mathrm{~g}$ (active ingredient [ai]) of azoxystrobin per ha had the lowest Rhizoctonia crown and root rot index (1.89) and was not statistically different from the $304 \mathrm{~g}$ ai/ha rate of azoxystrobin fungicide applied alone (1.99), while the BCA alone had a disease index of 2.63 and the $76 \mathrm{~g}$ ai/ha rate of azoxystrobin had a disease index of 2.44. In other work on this topic, Jacobsen et al. (12) showed similar results with another strobilurin fungicide, pyraclastrobin. The use of MSU 127 in combination with these fungicides allows the rate of fungicide to be reduced by $50 \%$ without loss of efficacy.

In studies on bacterial spot of pepper, Wright and Miller (30) showed that Gustafson Biologicals LS 213, LS 254, and LS 257 (all preparations containing Bacillus, Brevibacillus, and Paenibacillus spp.) or Paenibacillus macerans isolate OSU 142 incorporated into the transplant media (Gustafson LS preparations) or used as a transplant dip (OSU 142) provided better control when used with foliar applications of Kocide 101 or Kocide 101 plus Manex than the bacterial treatments or the Kocide plus Manex treatments alone. Kiewnick and Jacobsen (15) showed that Bacillus isolates MSU 129, MSU 131, and MSU 133 combined with

TABLE 1. Integration of varietal resistance to Cercospora leaf spot, fungicides, fungicide application number, and the biological control $\mathrm{Bm} \mathrm{J}$ for management of Cercospora leaf spot of sugarbeet data for 2001 and 2002 combined

\begin{tabular}{|c|c|c|c|c|}
\hline \multirow[b]{2}{*}{ Treatment } & \multicolumn{2}{|c|}{ Beta $2185 \mathrm{KWS}^{\mathrm{a}}=6.3$} & \multicolumn{2}{|c|}{$\mathrm{HM} 7054 \mathrm{KWS}^{\mathrm{a}}=4.3$} \\
\hline & $\mathrm{AUDPC}^{\mathrm{b}}$ & $\begin{array}{l}\text { Sugar } \\
\text { (kg/ha) }\end{array}$ & $\mathrm{AUDPC}^{\mathrm{b}}$ & $\begin{array}{l}\text { Sugar } \\
\text { (kg/ha) }\end{array}$ \\
\hline Unsprayed & 55.7 & 8,989 & 34.7 & 9,581 \\
\hline 4 sprays $^{c}$ & 19.3 & 9,940 & 11.9 & 10,192 \\
\hline 3 sprays & 22.8 & 9,485 & 11.4 & 9,796 \\
\hline 2 sprays & 22.3 & 9,495 & 15.7 & 9,706 \\
\hline $\begin{array}{l}\text { Bm } \mathrm{J} \text { preventive }+14, \\
28, \text { and } 42 \text { days }\end{array}$ & 46.7 & 10,148 & 21.2 & 9,830 \\
\hline $\begin{array}{l}\text { Tetraconazole } 0.075 \\
\text { liter/ha }+ \text { Bm J onset }+ \\
\text { Bm J 14, 28, and } 42 \text { days }\end{array}$ & 25.3 & 10,056 & 18.2 & 9,521 \\
\hline FLSD $0.05^{\mathrm{d}}$ & 4.15 & 659 & 4.15 & 659 \\
\hline
\end{tabular}

${ }^{a}$ Score for Cercospora leaf spot severity based on the 1-to-9 Kleinwanzleber Saatzucht (KWS) scale. Cultivars with lower KWS scores are more resistant to Cercospora leaf spot.

b AUDPC $=$ area under the disease progress curve.

c Mean of spray at disease onset plus 14, 28, and 42 days and Minnesota predictive model since they were the same. First spray at disease onset for $2001=$ tetraconazole at 0.15 liter/ha, second spray = benomyl at $92 \mathrm{~g} / \mathrm{ha}$, and third and fourth spray = triphenyltin hydroxide at $57 \mathrm{~g} /$ ha; and 2002 first spray = tetraconazole at 0.15 liter/ha, second spray $=$ trifloxystrobin at $110 \mathrm{ml} / \mathrm{ha}$, third spray $=$ triphenyltin hydroxide at $57 \mathrm{~g} / \mathrm{ha}$, and fourth spray $=$ trifloxystrobin at $110 \mathrm{ml} / \mathrm{ha}$.

${ }^{\mathrm{d}}$ FLSD $=$ Fisher's least significant difference . 
thiabendazole provided better control of Fusarium dry rot of potato than thiabendazole or the BCAs alone regardless of whether the $F$. sambucinum isolate used was sensitive or insensitive to thiabendazole.

Combinations of BCAs. Control of plant diseases by BCAs depends on interaction with the host, most commonly by colonization or establishment on the phyllosphere or rhizosphere, or by induction of induced resistance. This is clearly affected by the environment, and combinations of BCAs may allow for greater consistency of control when they are selected to be adapted over a range of environmental conditions. In addition, mixtures may confront the pathogen or pathogens with different modes of action. Unfortunately, most reports on Bacillus-based BCAs are for single isolates or in comparison to other BCAs used alone. The following examples illustrate the benefits of combinations of BCAs.

Research by Guetsky et al. (7) showed that control of Botrytis cinerea on strawberry leaves was more consistent over a range of environmental conditions when a yeast, Picha guilermondii, was applied with Bacillus mycoides isolate B16 than that of either organism applied alone. Under specific environmental conditions, each of the organisms was superior to the other, but for control over the range of environments ( 1 to $30^{\circ} \mathrm{C}$ and 78 to $100 \%$ relative humidity) the coefficient of variability was reduced from 9.7 to $75 \%$ when these BCAs were applied alone to 0.4 to $9.0 \%$ when both BCAs were applied together. Another example of the effect of environment is the work of Raupach and Kloepper (26), who showed that, when Bacillus subtilis isolate INA7 was used with Bacillus subtilis isolate GBO3 and Curtobacterium flaccumfaciens isolate ME1 as seed treatments, greater growth promotion and numerically better angular leaf spot control of cucumber was achieved where methyl bromide fumigation was used compared with that of nonfumigation. This latter mixture of BCAs is the basis for the BioYield product marketed by Gustafson Inc., Plano, TX.

Besides variability in environments, pathologists and others are confronted with control of multiple diseases on the same crop or cropping system. The importance in selecting Bacillus-based BCAs adapted to specific environments is shown in the research reported by Leibinger et al. (21), where Bacillus subtilis isolates AG704 and HG77 showed good colonization of apples in the field but poor colonization and apple fruit rot control in storage compared with that of two yeast species. Leibinger et al. (21) also demonstrated that compatibility between BCAs is important in that the yeast Aureobasidium pullans was reduced by the Bacillus BCAs with a resultant decrease in efficacy when these BCAs were mixed. Jetiyanon et al. (13) showed similar benefits for mixtures of Bacillus spp. applied as seed treatments. They studied $\mathrm{Ba}$ cillus amyloliquefaciens isolate IN937A applied alone and in combination with Bacillus pumilis strains SE34, SE49, T4, and INR7 and demonstrated greater growth promotion and anthracnose disease control in the winter season on long cayenne pepper with the combinations than with IN937A alone. Control of southern blight on tomato, growth promotion on tomato, and control of Cucumber mosaic virus and growth promotion on cucumber were not improved by using combinations. Thus, mixtures may not work with all crops or pathosystems.

Combining cultural controls with Bacillus-based BCAs. Cultural controls are the basic means of disease management in traditional farming systems (29) and are the resilient skeleton on which all other pest management practices depend in most cropping systems (10). Research papers that address the incorporation of Bacillus-based BCAs with crop rotation, tillage, plant nutrition, sanitation, selection of favorable environments for planting, and improved drainage, etc., have not been found for this review, except for work by Ploper et al. (25). They showed that, when mixtures of two Bacillus cereus isolates were used with plastic row mulches, control of tomato early blight was equal to the control achieved with weekly applications of chlorothalonil on toma- toes grown on bare soils. Clearly, there is research needed that tests the hypothesis that BCAs perform better under conditions that are less favorable to disease development.

Use of Bacillus-based BCAs in fungicide resistance management. Integration of BCAs into pesticide resistance management strategies has not been well explored. However, use of different modes of action in sequential fungicide applications is considered a keystone of resistance management programs $(9,18)$. Because Bacillus-based BCAs have modes of action different from that of synthetic chemical fungicides, it is logical that they can be used in fungicide resistance management programs. Bacillus-based BCAs have modes of action that include antibiosis, parasitism, and induced systemic resistance $(1,10)$. Larson (20) studied the prevalence of benomyl, azoxystrobin, and tetraconazole resistance of Cercospora beticola for 2 years in replicated plots that received no treatments, a rotation of different classes of labeled fungicides, Bacillus mycoides isolate $\mathrm{Bm} \mathrm{J}$, or a program that integrated $\mathrm{Bm} \mathrm{J}$ with these fungicides. In the first year of the study, use of $\mathrm{Bm} \mathrm{J}$ alone did not reduce the percentage of conidia insensitive to $1 \mathrm{ppm}$ of benomyl, azoxystrobin, or tetraconazole. However, the Bm J plus fungicide treatments had a statistically smaller percentage of conidia insensitive to $1 \mathrm{ppm}$ of benomyl and tetraconazole than the plots treated with the rotation of fungicides and was equal to the fungicide rotation plots for azoxystrobin insensitivity. In 2002, no reduction of fungicide resistance was noted. Because these plots were only 3 by $10 \mathrm{~m}$, it is likely that spores blown or splashed from adjacent plots masked treatment effects. For mycelial growth tests for insensitivity there were no statistical differences between treatments in either year.

Matheron and Porchas (22) reported on the use of Serenade (Bacillus subtilis isolate QST 713) alternated with sulfur (Microthiol 80DF), myclobutanil (Rally 40W), or trifloxystrobin (Flint 50WG) for control of powdery mildew of lettuce. Treatments in which four sprays of sulfur $(8.96 \mathrm{~kg} / \mathrm{ha})$ or Serenade ( $2.24 \mathrm{~kg} / \mathrm{ha})$ plus sulfur (4.48 to $8.96 \mathrm{~kg} / \mathrm{ha})$ were applied were not statistically different, whereas Serenade alone $(2.24$ to $4.48 \mathrm{~kg} / \mathrm{ha})$ provided statistically more mildew damage. Alternate sprays of myclobutanil (70.6 $\mathrm{g}$ ai/ha) or trifloxystrobin (69 $\mathrm{g}$ ai/ha) with Serenade provided control not statistically different from that achieved with four applications of trifloxystrobin or myclobutanil. Thus, alternate sprays with the BCA Serenade saved 8.96 to $20.16 \mathrm{~kg}$ of sulfur per ha, $139 \mathrm{~g}$ ai of trifloxystrobin per ha, or $141 \mathrm{~g}$ ai/ha and achieved the same results. In addition, by using different modes of action, Matheron and Porchas (22) proposed that the BCA contributed to a fungicide resistance management program.

Concluding comments. This review points out the relative paucity of research involving integration of Bacillus-based BCAs with other disease management tools. We strongly encourage biological control researchers to not only compare the level of control achieved with BCAs to that of synthetic chemical standards but to make comparisons that integrate resistant cultivars, cultural controls, reduced rates of pesticides, and other BCAs. It is only with these types of comparisons that the full potential for integrating BCAs into modern production agriculture will be achieved. In addition, the use of BCAs as replacements for fungicides or bactericides with high potential for development of resistance under low disease pressure may provide for less fungicide selection pressure on pathogen populations. It is of interest that most Bacillus-based BCA product labels contain language that integration of these products within an overall IPM strategy is desirable. It is critical that the research base be built to make science-based recommendations for integration of BCAs into IPM systems.

\section{LITERATURE CITED}

1. Bargabus, R. L., Zidack, N. K., Sherwood, J. E., and Jacobsen, B. J. 2002. Characterisation of systemic resistance in sugar beet elicited by a non- 
pathogenic, phyllosphere-colonizing Bacillus mycoides, biological control agent. PMPP 61:289-298.

2. Batson, W. E., Caceres, J., Elliott, M. L., Huber, D. M., Hickman, M. V., McLean, K. S., Ownley, B., Newman, M., Padgett, G. B., Kenny, D. S., Rothrock, C. S., Seebold, K., and Thaxton, P. 2002. Biological seed treatment evaluations for control of the cotton seedling disease complex, 2001. Biol. Cult. Tests 18:F002.

3. Batson, W. E., Jr., Benson, M., Cubeta, M. A., Elliott, M. L., Isakeit, T., McClean, K. S., Padgett, G. B., Rothrock, C. S., and Seebold, K. 2003. Evaluation of selected biological seed treatments for cotton seedling disease control, 2002. Biol. Cult. Tests 18:F003.

4. Brannen, P. M., and Kenney, D. S. 1997. Kodiak-A successful biological-control product for suppression of soil-borne plant pathogens of cotton. J. Ind. Microbiol. Biotechnol. 19:169-171.

5. Cook, R. J., Weller, D. M., El-Banna, A. Y., Vakoch, D., and Zhang, J. 2002. Yield responses of direct-seeded wheat to rhizobacteria and fungicide seed treatments. Plant Dis. 86:780-784.

6. Everts, K. L., and Armentrout, D. K. 2001. Evaluation of the effectiveness of bio-fungicides, ground cover and host resistance in reducing diseases of pumpkin. Biol. Cult. Tests 17:V18.

7. Guetsky, R., Shtienberg, D., Elad, Y., and Dinoor, A. 2001. Combining biocontrol agents to reduce the variability of biological control. Phytopathology 91:621-627.

8. Hervas, A., Landa, B., Datnoff, L. E., and Jimenez-Diaz, R. M. 1998. Effects of commercial and indigenous microorganisms on Fusarium wilt development in chickpea. Biol. Control 13:166-176.

9. Jacobsen, B. J. 2004. Resistance management strategies for plant pathogens. Page 150 in: Management of Pest Resistance: Strategies Using Crop Management, Biotechnology, and Pesticides. Special Publication No. 24. Council for Agricultural Science and Technology, Ames, IA.

10. Jacobsen, B. J., and Backman, P. A. 1993. Biological and cultural plant disease controls: Alternatives and supplements to chemicals in IPM systems. Plant Dis. 77:311-315.

11. Jacobsen, B. J., Larson, B., Zidack, N. K., Ansley, J., Eckhoff, J. L. A., and Bergman, J. 2002. Integrated management of Cercospora leaf spot. Sugarbeet Res. Ext. Rep. 33:235-240.

12. Jacobsen, B. J., Zidack, N., Kephart, K., and Ansley, J. 2002. Integrated management strategies for Rhizoctonia crown and root rot. Sugarbeet Res. Ext. Rep. 33:258-259.

13. Jetiyanon, K., Fowler, W. D., and Kloepper, J. W. 2003. Broad-spectrum protection against several pathogens by PGPR mixtures under field conditions in Thailand. Plant Dis. 87:1390-1394.

14. Kenney, D. S., Howell, C. R., and Minton, E. B. 1992. Studies on the mode of action of Bacillus subtilis as a biocontrol agent in cotton. Page 198 in: Proc. Beltwide Cotton Research Conference. National Cotton Council, Memphis, TN.

15. Kiewnick, S., and Jacobsen, B. J. 1996. Biological control of Fusarium dry rot on potato with antagonistic bacteria in commercial formulation. Phytopathology 86:S48.

16. Kiewnick, S., Jacobsen, B. J., Braun-Kiewnick, A., Eckhoff, J. L. A., and Bergman, J. W. 2001. Integrated control of Rhizoctonia crown and root rot of sugar beet with fungicides and antagonistic bacteria. Plant Dis. 85:718-722.

17. Kleinwanzlebener Saatzucht Ag. 1970. Cercospora Tafel. Kleinwanzlebener Saatzucht Ag., Rabbethge \& Giesecke, Niedersachen, Germany.

18. Koeller, W. 2004. Pathogens. Page 17 in: Management of Pest Resistance: Strategies Using Crop Management, Biotechnology, and Pesticides. Special Publication No. 24. Council for Agricultural Science and Technology, Ames, IA.

19. Korsten, L., De Villiers, E. E., Wehner, F. C., and Kotze, J. M. 1997. Field sprays of Bacillus subtilis for control of preharvest fruit diseases of avocado in South Africa. Plant Dis. 81:455-459.

20. Larson, B. 2004. Integrated management of Cercospora leaf spot. M.S. thesis. Montana State University, Bozeman.

21. Leibinger, W., Breuker, B., Hahn, M., and Mendgen, K. 1997. Control of postharvest pathogens and colonization of the apple surface by antagonistic microorganisms in the field. Phytopathology 87:1103-1110.

22. Matheron, M. E., and Porchas, M. 2000. Evaluation of fungicide performance for control of powdery mildew on lettuce in 2000. Online publication no. AZ1177 in: Vegetable: College of Agriculture Report 2000, College of Agriculture, the University of Arizona, Tucson.

23. McGovern, R. J. 2001. Evaluation of biological control and cultivar resistance for management of basil diseases. Biol. Cult. Tests 17:V01.

24. Osburn, R. M., Milner, J. L., Oplinger, E. S., Smith, R. S., and Handelsman, J. 1995. Effect of Bacillus cereus UW85 on the yield of soybean at two field sites in Wisconsin. Plant Dis. 79:551-556.

25. Ploper, L. D., Backman, P. A., Stevens, C., Khan, V. A., and RodriquezKabana, R. 1992. Effects of soil mulch, row cover, and biological and chemical foliar treatments on early blight of tomato. Biol. Cult. Tests $7: 38$

26. Raupach, G. S., and Kloepper, J. W. 1998. Mixtures of plant growthpromoting rhizobacteria enhance biological control of multiple cucumber pathogens. Phytopathology 88:1158-1164.

27. Rossi, V., Giosue, S., and Racca, P. 1999. A model integrating components of rate-reducting resistance to Cercospora leaf spot in sugar beet. J. Phytopathol. 147:339-346.

28. Smith, K. P., Handelsman, J., and Goodman, R. M. 1997. Modeling doseresponse relationships in biological control: Partitioning host responses to the pathogen and biocontrol agent. Phytopathology 87:720-729.

29. Thurston, H. D. 1990. Plant disease management practices of traditional farmers. Plant Dis. 74:96-102.

30. Wright, S., and Miller, S. A. 2001. Evaluation of Bacillus, Brevibacillus, and Paenibacillus spp. for management of tomato diseases. Biol. Cult. Tests 16:PT75. 